\title{
Flaxseed protein: extraction, functionalities and applications
}

\author{
Xin-Pei YE ${ }^{1 *}$, Ming-Feng XU"1* , Zhen-Xing TANG ${ }^{2}$, Hang-Jie CHEN ${ }^{1}$, Dan-Ting WU ${ }^{1}$, Zheng-Yun WANG ${ }^{1}$, \\ Yuan-Xiao SONGZHEN ${ }^{1}$, Juan $\mathrm{HAO}^{1}$, Li-Min WU ${ }^{1}$, Lu-E SHI ${ }^{1 \star}$
}

\begin{abstract}
Flaxseed (Linum usitatissimum L.), one kind of common oilseeds, has many biologically active compounds including a-linolenic acid (ALA), lignan and dietary fiber. At present, the research of flaxseed is focused on biological and clinical studies of its compounds. However, the studies of flaxseed protein obtained generally from flaxseed cake, are relatively limited. As many other kinds of plant proteins, flaxseed protein presents many excellent functionalities which can be used for food applications. Many evidence have showed that flaxseed protein hydrolysates can provide health benefits to our body, such as anti-bacterial activity, antioxidant capacity and angiotensin-converting enzyme inhibition ability. Therefore, in order to make better use of flaxseed protein in foods, the extraction, functionalities and applications of flaxseed protein were reviewed in this paper. In addition, the preparation of flaxseed protein hydrolysates was discussed.
\end{abstract}

Keywords: flaxseed protein; extraction; functionalities; hydrolysis; application.

Practical Application: This review provides the extraction, functionalities of flaxseed protein, discussing the preparation of flaxseed protein hydrolysates, with the aim to improve the applications of flaxseed protein in food industry.

\section{Introduction}

Flaxseed, one kind of oilseeds, is worldwide grown in more than 50 countries. The global production output of flaxseed in 2018 is reached to 3.183 million tons (Food and Agriculture Organization, 2020). Canada and China are the major producers of flaxseed, which account for around 33\% of the total world output (Bekhit et al., 2018; Tang et al., 2021). Due to the high contents of ALA in flaxseed oil, lignans, dietary fibers and flaxseed proteins, the scientists have been showing the great enthusiasm for flaxseed studies (Marambe \& Wanasundara, 2017; Wu et al., 2019; Yang, et al., 2021; Zou et al., 2017). At present, many flaxseed-based products, such as whole flaxseeds, ground/milled flaxseeds, flaxseed oil, and lignan extracts, have been available (Shim et al., 2015). Particularly, the applications of flaxseed oil in many food systems, have been carried out (Lim et al., 2010; Tang \& Bian, 2018a, b, c, d, e; Tang, 2019a, b; Tang et al., 2020, 2021). As for flaxseed protein, the studies are relatively limited due to anti-nutritional substances in flaxseed meal (Safdar et al., 2020). Moreover, because the potential health values of flaxseed proteins are not investigated sufficiently, flaxseed protein is generally used as a feed additive, not as one kind of food protein sources (Kuang et al., 2020; Logarušić et al., 2020).

Amino acids are necessary to support our growth. Although most of amino acids can be synthesized in our body, only nine kinds of essential amino acids (EAA) must be supplied through the diet. Flaxseed protein has the similar EAA profiles with soybean protein, but is inferior to egg protein (Bekhit et al.,
2018; Marambe \& Wanasundara, 2017; Udenigwe \& Aluko, 2011). Marambe et al. (2011) reported that flaxseed protein had around $34.3 \%$ EAA, providing a great potential for taking flaxseed as one kind of protein sources. Flaxseed protein (or meal) is abundant of branched-chain amino acids (valine and leucine) and aromatic amino acids (tyrosine and phenylalanine) (Oomah, 2001; Zardo et al., 2009). Thus, flaxseed protein can be utilized to develop flaxseed-based functional foods. Recently, the effect of the processing treatments on functional characteristics of flaxseed protein and the development of flaxseed protein in foods have been studied (Lan et al., 2020; Nwachukwu \& Aluko, 2018b; Tirgar et al., 2017; Wanasundara \& Shahidi, 2003). An increasing number of evidence have demonstrated that flaxseed protein and its hydrolysates exhibit many health promoting benefits (Franck et al., 2019; Marie et al., 2019; Nwachukwu \& Aluko, 2018a; Shi et al., 2021; Wei et al., 2018). Therefore, to increase the added value of flaxseed protein, we showed a review of the latest development of extraction, functionalities and applications of flaxseed protein in this paper. The preparation of flaxseed protein hydrolysates was also presented.

\section{Nutritional properties of flaxseed and its protein}

The concentration of the compositions in flaxseed varies widely, which is dependent on many factors, such as cultivars, growing environments. Generally, the contents of flaxseed oil, dietary fibre, protein, and lignan, are $38-45 \%, 18-28 \%, 20-28 \%$, 
Table 1. Nutritional composition of whole flaxseed.

\begin{tabular}{|c|c|}
\hline Nutritional composition & The contents/ $100 \mathrm{~g}$ of flaxseed \\
\hline \multicolumn{2}{|c|}{ Proximate composition $(\mathrm{g})$} \\
\hline Moisture & 6.96 \\
\hline Protein $(\mathrm{N} \times 6.25)$ & 18.3 \\
\hline Fat & 42.40 \\
\hline Total dietary fiber & 27.3 \\
\hline Carbohydrates & 28.9 \\
\hline \multicolumn{2}{|c|}{ Minerals (mg) } \\
\hline Calcium & 255 \\
\hline Phosphorous & 642 \\
\hline Iron & 5.73 \\
\hline Zinc & 4.34 \\
\hline Magnesium & 392 \\
\hline Potassium & 813 \\
\hline Sodium & 30 \\
\hline Copper & 1.22 \\
\hline \multicolumn{2}{|c|}{ Vitamins (mg) } \\
\hline Vitamin A & 0 \\
\hline Vitamin E & 23.3 \\
\hline Thiamine $\left(\mathrm{B}_{1}\right)$ & 1.64 \\
\hline Riboflavin $\left(\mathrm{B}_{2}\right)$ & 0.161 \\
\hline Niacin & 3.08 \\
\hline Vitamin C & 0.60 \\
\hline Vitamin D & 0 \\
\hline Vitamin $\mathrm{B}_{6}$ & 0.473 \\
\hline
\end{tabular}

and $0.8-1.3 \%$, respectively (Rabetafika et al., 2011; Tang et al., 2020, 2021). The composition of whole flaxseed was showed in Table 1. The level of flaxseed protein in whole flaxseed changes widely from 10 to $31 \%$, which depends on many factors, for example cultivars, environmental conditions and processing methods (Chung et al., 2005). Flaxseed protein mainly consists of 11-12S globulin and 1.6-2S albumin. 11-12S globulin, a salt-soluble protein, has high molecular weight $(252-298 \mathrm{kDa})$, whereas 1.6-2S albumin, a water-soluble protein, exhibits low molecular weight (16-17 kDa) (Arntfield, 2018; Sammour et al., 1994; Sammour, 1999). 11-12S globulin named as linin, accounts for $64-85 \%$ of total flaxseed protein (Arntfield, 2018; Lei et al., 2003; Marambe \& Wanasundara, 2017). 11S globulin has four subunits $(36,46,50$, and $55 \mathrm{kDa})$, which are linked by disulfide bonds (Krause et al., 2010). 1.6-2S albumin of flaxseed protein termed as colinin, has a single polypeptide chain with 168 or 169 amino acids, and is occupied for about $40-42 \%$ of flaxseed protein (Bekhit et al., 2018; Marambe \& Wanasundara, 2017; Sammour, 1999). Compared to 11-12S globulin, 1.6-2S albumin possesses a much more ordered structure and more disulfide linkages (Bakowska-Barczak et al., 2020).

Many factors, for instance flaxseed cultivars, environmental conditions, and processing conditions, can affect amino acid profiles of flaxseed protein (Dash et al., 2021). The amino acid compositions of flaxseed protein were showed in Table 2. Flaxseed protein is enriched in arginine, aspartic acid, and glutamic acid, whereas it is poor in sulphur-containing amino acids, for example methionine, cysteine (Hall et al., 2006; Juodeikiene, et al., 2020; Marambe \& Wanasundara, 2017; Oomah \& Mazza, 1993). Lysine

Table 2. Amino acid composition of flaxseed protein.

\begin{tabular}{|c|c|c|c|c|}
\hline Amino acids & $\begin{array}{l}\text { Requirement pattern } \\
(\mathrm{mg} / \mathrm{g} \text { protein })^{\mathrm{a}}\end{array}$ & $\begin{array}{l}\mathrm{mg} / \mathrm{g} \text { protein }{ }^{\mathrm{b}} \\
\text { (Norlin cultivar) }\end{array}$ & $\mathrm{mg} / \mathrm{g}$ protein ${ }^{\mathrm{c}}$ & Amino acid score $(\%)^{d}$ \\
\hline \multicolumn{5}{|l|}{ Essential Amino acid } \\
\hline Histidine & 15 & 22 & 31.7 & $211 \pm 1$ \\
\hline Isoleucine & 30 & 40 & 34.2 & $114 \pm 1$ \\
\hline Leucine & 59 & 58 & 65.2 & $110 \pm 1$ \\
\hline Lysine & 45 & 40 & 41.9 & $93 \pm 1$ \\
\hline Methionine & - & - & 261.1 & - \\
\hline Methionine + Cysteine & 22 & 26 & - & - \\
\hline Cysteine & - & - & 14.4 & - \\
\hline Threonine & 23 & 36 & 40.2 & $175 \pm 1$ \\
\hline Phenylalanine & - & - & 44.0 & - \\
\hline Phenylalanine + Tyrosine & 25 & 69 & - & - \\
\hline Valine & 39 & 46 & 41.2 & $106 \pm 1$ \\
\hline \multicolumn{5}{|l|}{ Nonessential Amino acid } \\
\hline Alanine & & 44 & 51.8 & \\
\hline Arginine & & 92 & 114.2 & \\
\hline Aspartic acid & & 93 & 119.1 & \\
\hline Glutamic acid & & 196 & 195.6 & \\
\hline Glycine & & 58 & 42.6 & \\
\hline Proline & & 35 & 47.9 & \\
\hline Serine & & 45 & 52.8 & \\
\hline
\end{tabular}

${ }^{\mathrm{a}}$ Expert consultation reports for the adults; ${ }^{\mathrm{b}}$ Marambe et al. (2011); ${ }^{\mathrm{c} B a k o w s k a-B a r c z a k}$ et al. (2020); ${ }^{\mathrm{d}}$ Amino acid score: (mg of amino acid in $1 \mathrm{~g}$ of test protein/mg of amino acid in requirement pattern) $\times 100$. Amino acid score was calculated based on the data from Marambe et al. (2011). 
is generally considered as the limiting amino acid (Table 2; Chung et al., 2005). Therefore, before starting the development of flaxseed protein-based foods, we should know that flaxseed protein can only satisfy the amino acid nutritional requirements for the adults. It is not a good protein source for baby due to the limited amino acid levels of lysine (Marambe \& Wanasundara, 2017; Udenigwe \& Aluko, 2011). In order to make up for the deficiency of lysine in flaxseed protein, the complementary proteins enriched with lysine should be added. Germination can significantly change the contents of amino acids in flaxseed (Lv \& Huang, 2015). Wanasundara et al. (1999) found that the total amino acids concentration in flaxseed increased by around 15 times after an 8-day of germination. The contents of glutamine and leucine were significantly improved.

\section{Extraction of flaxseed protein}

At present, most studies regarding extraction processes for flaxseed protein are at a laboratory scale. The major obstacle to extract flaxseed protein is the mucilage distributed in the outer layer of flaxseed (Marambe \& Wanasundara, 2017). The mucilage can improve the extract viscosity, and thus decreases the extraction efficiency. Therefore, some attempts, such as enzymatic or physicochemical ways, have been adopted to remove or reduce the mucilage level before flaxseed protein extraction is carried out (Liu et al., 2018; Marambe \& Wanasundara, 2017). The physical dehulling for flaxseed is one of the pretreatment processes to extract flaxseed protein. Wet and dry extraction methods have been developed to remove flaxseed mucilage (Karaca et al., 2011; Kaushik et al., 2016; Lan et al., 2020; Mridula et al., 2014). The dehulling efficiency is highly influenced by various factors, for example the speed, dehulling time, and the moisture in flaxseed (Zheng et al., 2003). Due to multiple steps involved in wet extraction process, wet process is not economical to extract flaxseed protein. Currently, the main dehulling method is a dry extraction process (Li \& Hao, 2013). The method that using polysaccharide-degrading enzymes to degrade the mucilage in flaxseed, has been investigated by some researchers. Through the combination of $\mathrm{NaHCO}_{3}$ soaking and Viscozyme (Novozyme, 100 Fungal $\beta$ glucanase $/ g$ ) to treat whole flaxseed, protein extraction efficiency could be improved significantly compared to only $\mathrm{NaHCO}_{3}$ soaking to treat whole flaxseed (Slominski et al., 2006; Wanasundara \& Shahidi, 1997). Song et al. (2017) also showed that the de-mucilaged rate could be reached to $94.7 \%$ under the optimized pectinase hydrolysis conditions.
Protein concentration in defated flaxseed meal (DFM), the by-product of flaxseed pressing, usually changes from 35 to $40 \%$, that indicates that DFM is an excellent source to obtain flaxseed protein (Lan et al., 2020; Marambe \& Wanasundara, 2017; Nwachukwu \& Aluko, 2018b; Sa et al., 2021; Tang et al., 2021; Tirgar et al., 2017). Some processing factors, such as solvent composition, $\mathrm{pH}$, heating treatment, solvent/meal ratio, and salt concentration, can significantly affect the solubility of flaxseed protein (Tirgar et al., 2017). Many methods, such as alkali-aided solubilization/isoelectric precipitation, buffered salt or polyphosphate extraction, micellization, have been developed to extract flaxseed protein (Kaushik et al., 2016; Nwachukwu \& Aluko, 2018b; Pham et al., 2019b; Teh et al., 2014). Some of these methods used to obtain flaxseed protein were given in Table 3. Of all employed methods, alkali extraction is one of the most popular methods. As most of oilseed proteins, flaxseed protein is soluble at alkaline conditions. Flaxseed protein can be extracted from DFM at $\mathrm{pH}$ values from 8.5 to 11.0 or under the existence of $\mathrm{NaCl}$. However, the extraction at extreme alkaline conditions may cause undesirable modification of proteins, and even unpredicatable reactions. Therefore, the extraction $\mathrm{pH}$ for flaxseed protein is preferred from 7.0 to 9.0 (Pham et al., 2019b). After flaxseed protein is extracted in alkali solutions, $\mathrm{pH}$ needs to be adjusted to close to isoelectronic point (between 3.5 and 4.4) (Karaca et al., 2011; Lan et al., 2020; Nasrabadi et al., 2019). Alkaline-aided extraction/isoelectric precipitation method is not suitable to extract flaxseed protein as the mucilage in flaxseed hull may disturb the protein precipitation. In the study of Kaushik et al. (2016), the de-mucilaged DFM was soaked in $\mathrm{pH} 8.6$ tris buffer for $24 \mathrm{~h}$, and then flaxseed protein was precipitated after $\mathrm{pH}$ was adjusted to $\mathrm{pH} 4.2$.

Nwachukwu \& Aluko (2018b) obtained flaxseed albumin and globulin after DFM was extracted with $\mathrm{NaCl}$ for $1 \mathrm{~h}$ at room temperature. Perreault et al. (2017) also extracted flaxseed protein isolate from DFM. In their study, $\mathrm{pH}$ of flaxseed extracts was adjusted to 5.0, afterwards cellulase was added in order to hydrolyze the fibers. Flaxseed protein content could reach up to $82 \%$. Ribeiro et al. (2013) used the enzyme-assisted method to extract flaxseed protein. The yield of flaxseed protein (15.2\%) was obtained when DFM was agitated at the speed of $200 \mathrm{rpm}$, and treated by the mixture of ultrazyme, viscozyme and alcalase under $50^{\circ} \mathrm{C}$ for $1.5 \mathrm{~h}$. Tirgar et al. (2017) found that the higher flaxseed protein content $(86.8 \%)$ could be obtained by employing the combination of an alkaline-aided/isoelectric precipitation

Table 3. The extraction for flaxseed protein.

\begin{tabular}{|c|c|c|c|}
\hline $\begin{array}{c}\text { Raw materials for } \\
\text { extracting }\end{array}$ & Extraction Conditions & Protein Content (\%) & References \\
\hline DFM & \multirow{6}{*}{$\begin{array}{l}\text { pH 9.5, precipitation at } \mathrm{pH} 4.2 \\
\text { pH 8.0, with } \mathrm{Na}_{3} \mathrm{PO}_{4} \text { containing } 0.80 \mathrm{M} \mathrm{NaCl} \text { (solvent:meal ratio of 10) } \\
\text { pH 8.6, with tris buffer (solvent:meal ratio of } 16 \text { ) } \\
\text { pH 8.5, meal to solvent ratio of } 1: 10 \text {, precipitation at } \mathrm{pH} 3.8 \\
\text { Fiber hydrolysis by cellulase at } \mathrm{pH} 5.0 \text {, precipitation at } \mathrm{pH} 4.2 \\
\text { pH 9.5, precipitation at pH } 4.0 \\
\text { pH 8.6, seed to meal ratio of } 1: 16 \text {, precipitation at } \mathrm{pH} 4.2\end{array}$} & $93.7 \%$ & Mohamed et al. (2020) \\
\hline DFM & & $87.39 \%$ & Karaca et al. (2011) \\
\hline DFM & & $93.6 \%$ & Pham et al. (2019b) \\
\hline Whole flaxseed & & $80.2 \%$ & Marambe et al. (2008) \\
\hline DFM & & $82 \%$ & Perreault et al. (2017) \\
\hline Whole flaxseed & & $90.6 \%$ & Kaushik et al. (2016) \\
\hline DFM & $\mathrm{pH} 8.5$, precipitation at 4.2 & $61.38 \%$ & Lan et al. (2020) \\
\hline
\end{tabular}


plus the treatment of cellulase extraction/ethanol precipitation for the extracts, compared to alkaline-aided/isoelectric precipitation or cellulase treatment alone.

\section{Functional properties of flaxseed protein}

As other oilseed proteins, flaxseed protein exhibits many functional characteristics, for example water/oil adsorption ability, solubility, emulsion capacity, and foaming capacity (Mohamed et al., 2020; Sharma \& Saini, 2021; Shi et al., 2021; Wang et al., 2010). These characteristics are significantly affected by various factors including temperature, ionic strength, $\mathrm{pH}$, the methods used for protein extraction, purity and particle size of the proteins (Krause et al., 2010; Martínez-Flores et al., 2006; Tirgar et al., 2017). The mucilage in flaxseed protein samples may affect functional properties of flaxseed protein (Rabetafika et al., 2011). It can improve water adsorption, the foaming and emulsifying properties of flaxseed protein, but, it decreases oil adsorption capacity of flaxseed protein (Lipilina \& Ganji, 2009; Rabetafika et al., 2011).

\subsection{Thermal denaturation}

The functional properties of plant proteins are highly related to their structures. As other oilseed proteins, the heating can alter the structure of flaxseed protein, and results in the change of functional characteristics of flaxseed protein. Kaushik et al. (2016) showed that flaxseed protein underwent two structural transitions during the heating. One was observed at a temperature around $53.72{ }^{\circ} \mathrm{C}$, the other was around $105.05^{\circ} \mathrm{C}$. Safdar et al. (2020) observed two endothermic peaks temperatures of defatted flaxseed flour at $88.49^{\circ} \mathrm{C}, 223.84^{\circ} \mathrm{C}$. Generally, the peaks around $100^{\circ} \mathrm{C}$ are related to the loss of water and initial denaturation of flaxseed protein. Similarly, Sharma \& Saini (2021) reported the denaturation temperature of flaxseed protein isolates obtained by alkali-aided solubilization/isoelectric precipitation, was $82.52^{\circ} \mathrm{C}$. Lan et al. (2020) showed that flaxseed protein concentrates showed better heating stability, and had higher denaturation temperature, compared to flaxseed protein isolates.

\subsection{Water/oil absorbing capacity}

Water and oil adsorbing capacities of flaxseed protein isolate could be comparable to those of other oilseed proteins (Kaushik et al., 2016). Kaushik et al. (2016) reported water/oil absorbing ability of flaxseed protein isolate was higher than that of most of the investigated proteins including soy protein, gelatin. The higher oil absorbing capacity of flaxseed protein isolate was attributed to their greater lipophilic property. Mohamed et al. (2020) reported water holding ability of flaxseed protein isolate was $11.4 \mathrm{~g} / \mathrm{g}$, while oil holding ability of flaxseed protein isolate was $1.47 \mathrm{~g} / \mathrm{g}$. In the study of Sharma \& Saini (2021), water and oil holding abilities of flaxseed protein isolate were reported to be $2.85 \mathrm{~g} / \mathrm{g}$ and $3.86 \mathrm{~g} / \mathrm{g}$, respectively. Oil adsorption capacity of food proteins is an important index for flavor retention and mouth-feel (Marambe \& Wanasundara, 2017). Flaxseed protein can be incorporated into emulsion-type meat products due to its good oil adsorption capacity. During cooking, flaxseed protein also can reduce fat losses, and thus decreases the weight loss of the products. Oil adsorption capacity of flaxseed protein concentrate was poorer compared to that of soybean protein concentrate, while it was higher than that of amaranth protein concentrate (Marambe \& Wanasundara, 2017; Martínez-Flores et al., 2006).

\subsection{Emulsifying capacity}

Flaxseed protein showed better emulsifying capacity compared to whey protein isolate and canola protein isolate, and a comparable creaming stability with canola and whey proteins (Karaca et al., 2011). Excessive heating treatment can destroy the structure of flaxseed protein, reduces the solubility, and thus significantly decreases emulsion capacity of flaxseed protein. Martínez-Flores et al. (2006) found that solvent, pH and temperature significantly affected emulsion capacity of flaxseed protein. Several studies indicated that alkali-solubilized flaxseed protein had high emulsifying capacity (Mueller et al., 2010; Sharma \& Saini, 2021; Yoshie-Stark et al., 2011). Tirgar et al. (2017) found that alkali-solubilized flaxseed protein concentrate exhibited the highest emulsion capacity (87.91\%) among the investigated proteins. The higher emulsion capacity of flaxseed protein concentrate was due to the high content of carbohydrate, compared to other protein concentrates which led to stabilize the emulsion efficiently. In addition, alkali-solubilized flaxseed protein concentrate showed the highest emulsion activity $\left(87.1 \mathrm{~m}^{2} / \mathrm{g}\right)$. Kaushik et al. (2016) obtained flaxseed protein (around 90\%) after flaxseed was de-mucilaged at $60^{\circ} \mathrm{C}$. The emulsion activity $\left(375.5 \mathrm{~m}^{2} / \mathrm{g}\right)$ of flaxseed protein was higher compared to that of investigated proteins including whey protein, soy protein and gelatine. Besides, the emulsions stabilized by flaxseed protein isolate showed higher stability at low pHs than those stabilized by the studied other proteins. Nwachukwu \& Aluko (2018b) suggested that flaxseed globulin had better emulsifying property at alkaline conditions, whereas flaxseed albumin exhibited better emulsifying property at acid conditions. Therefore, due to the suitable emulsifying property and good thermal stability of flaxseed protein, it has been used as a promising wall material to encapsulate bioactives (Pham et al., 2020).

Emulsifying capacity of flaxseed protein can be improved by structure modification, and the change of protein conformation (Juodeikiene et al., 2020; Nie et al., 2021; Pham et al., 2019a, b; Wang et al., 2010). Wanasundara \& Shahidi (1997) modified flaxseed protein by attaching acyl (acetyl or succinyl) groups, and showed that emulsion capacity of flaxseed protein with low degree of acetylation was higher compared to that of the unmodified. Nasrabadi et al. (2019) found that flaxseed protein-mulcilage complex nanoassemblies adsorbed onto the surface of emulsion could form a protecting coating to inhibit flocculation and coalescence, and thus improved the emulsion stability. Yu et al. (2020) also reported that emulsifying capacity of flaxseed protein was significantly improved following short time (5 15 s) treatment by atmospheric pressure plasma jet, which was among with the changes of spatial conformation of flaxseed protein.

\subsection{Foaming property}

As other oilseed proteins, foams are easily to be generated when flaxseed protein is whipped or stirred. Temperature and 
solvent $\mathrm{pH}$ significantly affect the foaming capacity and stability of flaxseed protein (Lan et al., 2020). In general, the foaming properties of plant proteins are higher in the acid environment, and the weakest foaming properties are observed in around isoelectronic point of proteins (Lan et al., 2020; Shevkani et al., 2015). Madhusudhan \& Singh (1985a, b) found that foaming formation capacity of flaxseed protein was kept as an stable state at $\mathrm{pH}$ 2.0-6.0. The foaming formation capacity of flaxseed protein was significantly improved after $\mathrm{pH}$ was adjusted above 8.0. Foaming stability of flaxseed protein could remain unchanged until $45^{\circ} \mathrm{C}$. After mild heating treatment for flaxseed protein $\left(45-80^{\circ} \mathrm{C}\right)$, the forming stability was highly improved due to the exposition of the hydrophobic groups of flaxseed protein. If the temperature increased more than $80^{\circ} \mathrm{C}$, the foaming stability would decrease significantly because the solubility of flaxseed protein decreased (Bekhit et al., 2018).

High foaming capacity of flaxseed protein at $\mathrm{pH} 10$ was observed by Martínez-Flores et al. (2006). However, flaxseed protein at $\mathrm{pH} 6$ exhibited the foaming capacity with low volume, but a high stability. In the study of Mueller et al. (2010), acidsoluble flaxseed protein with poor foaming capacity was also indicated. Lan et al. (2020) reported that flaxseed protein isolates showed significantly higher foaming capacity compared to flaxseed protein concentrates at investigated $\mathrm{pHs}$.

\section{Preparation of flaxseed protein hydrolysates for health benefits}

More evidence have showed that flaxseed protein can provide us health benefits (Akbarbaglu et al., 2019; Marie et al., 2019; Nwachukwu \& Aluko, 2018a; Udenigwe et al., 2009; Wei et al., 2018; Yu et al., 2020). Health benefits of flaxseed protein, such as anti-cholesterol, antioxidant, anti-tumour properties, antihyperglycemia, are attributed to the amino acid composition, the interaction with other compounds such as ALA, mucilage or phenolic compounds (Langyan et al., 2021; Rabetafika et al., 2011). Mohamed et al. (2020) found that flaxseed protein isolates had high antioxidant activity when flaxseed protein isolates was solubilized in lemon juice $(\mathrm{pH}=2-3)$. The lemon juice containing flaxseed protein isolates showed hepatorenal protective activity against lead on liver and kidney in rats. The health activities of flaxseed protein can be increased further through enzymatic hydrolysis (Silva et al., 2017; Teh et al., 2016). These hydrolysates have been attracted increasing attention, which provide beneficial activities to our health. Many health benefits of flaxseed protein hydrolysates, such as anti-hypertension ability, antibacterial activity, antioxidant capacity, anti-diabetic ability, and the inhibition ability of calmodulin-dependent neuronal nitric oxide synthase, have been reported (Franck et al., 2019; Logarušić et al., 2020; Nwachukwu \& Aluko, 2018a, b; Perreault et al., 2017; Silva et al., 2017; Udenigwe \& Aluko, 2010, 2012; Wu et al., 2019).

\subsection{Pre-treatment of flaxseed protein}

Many food-grade hydrolytic enzymes, including trypsin, Flavourzyme ${ }^{\circ}$, alcalase, thermolysin, pronase, pepsin, ficin, papain, pancreatin, Thermoase ${ }^{\circ}$, and protease from Bacillus altitudinis, have been employed to produce flaxseed protein hydrolysates using controlled or limited hydrolysis technology (Hwang et al., 2016; Karamać et al., 2016; Marambe et al., 2008, 2011; Nwachukwu \& Aluko, 2018a, b; Perreault et al., 2017; Sarabandi \& Jafari, 2020a, b; Udenigwe et al., 2012; Udenigwe \& Aluko, 2010; Wu et al., 2019). The digestibility of flaxseed protein is very important factor to affect the preparation of the hydrolysates. Many factors, for instance flaxseed ingredients (especially the mucilage and flaxseed oil), the pre-treatment methods, can significantly affect the digestibility of flaxseed protein. Thus, the pretreatment of raw material is assumed to be an important step for producing the hydrolysates (Franck et al., 2019; Marie et al., 2019; Perreault et al., 2017). The mucilage and oils in flaxseed can prevent the digestive enzymes from hydrolyzing flaxseed protein, and thus lead to the decrease of flaxseed protein digestibility. Therefore, the digestibility of flaxseed protein can be improved after the mucilage and oil in flaxseed are removed. Marambe et al. (2013) reported the protein digestibility in flaxseed meal could reach $66.8 \%$ after the mucilage and oil were removed, compared to $12.6 \%$ for ground flaxseed with the mucilage and full-fat. Perreault et al. (2017) improved the digestibility of flaxseed protein by high hydrostatic pressure technology, and also found antioxidant activity of protein hydrolysates was enhanced. Heating treatment such as home-style baking, boiling and extrusion process, also can improve the digestibility of flaxseed protein, which is due to the structural changes of flaxseed protein (Khan et al., 2015; Wang et al., 2008). Khan et al. (2015) found that flaxseed protein solubility decreased from 56.5 to $25.9 \%$ after flaxseed protein was treated by moist heating processing, and led to the increase of the protein digestibility. Through the pre-treatment investigations for flaxseed protein, flaxseed protein hydrolysates showed better functional and nutraceutical values compared to untreated flaxseed protein.

\subsection{Anti-hypertensive capacity}

The most extensive studies may be the anti-hypertensive activity among all the activities of flaxseed protein hydrolysates. Many flaxseed protein hydrolysates are prepared using single enzyme, complex enzyme preparation or enzyme combination, which can inhibit the angiotensin I-converting enzyme or renin activity (Marambe et al., 2008; Nwachukwu et al., 2014). Wu et al. (2009) obtained the hydrolysates from DFM by the use of alcalase, thermolysin or the combination of both enzymes. The half-maximal inhibitory concentration $\left(\mathrm{IC}_{50}\right)$ value of the hydrolysates generated by a combination of alcalase and thermolysin was $34.2 \mu \mathrm{g} / \mathrm{mL}$, while $\mathrm{IC}_{50}$ value of the hydrolysates through alcalase, thermolysin, were $64.3,37.1 \mu \mathrm{g} / \mathrm{mL}$, respectively. The authors indicated the hydrolysates obtained by a combination of alcalase and thermolysin showed better anti-hypertensive ability than those obtained by single enzyme.

Arginine-rich hydrolysates obtained from flaxseed protein showed a potential anti-hypertensive ability (Wu et al., 2019). Udenigwe et al. (2009) employed several proteases, such as pepsin, alcalase, trypsin, ficin, thermolysin, or pancreatin hydrolysis, to prepare flaxseed protein hydrolysates. The authors indicated $\mathrm{IC}_{50}$ values of the hydrolysates changed from 1.22 to $2.81 \mathrm{mg} / \mathrm{mL}$. The obtained cationic peptide fraction of alcalase-hydrolysates 
exhibited the highest activity. The same group (Udenigwe \& Aluko, 2010) produced flaxseed protein hydrolysates by thermolysin and pronase, and evaluated the activity of flaxseed protein hydrolysates in spontaneously hypertensive rates. The results manifested that the cationic fraction of the hydrolysates possessed lower systolic blood pressure ability than flaxseed protein isolates. Flaxseed protein isolates could decrease blood pressure effectively within $4 \mathrm{~h}$ after feeding flaxseed protein hydrolysates, however the cationic hydrolysates only needed $2 \mathrm{~h}$ to reach the similar levels.

Marambe et al. (2011) obtained the hydrolysates using the combination of pepsin-pancreatin under the simulated gastrointestinal digestion. The results indicated that anti-hypertensive activity of the hydrolysates obtained by pepsin-pancreatin was higher than that of pepsin-produced hydrolysates. In addition, the hydrolysis degree (43.95\%) obtained in dynamic digestion was higher than that from pepsin hydrolysis (7.96\%). Pancreatin is a mixture of enzymes including apancreatic amylase protease, pancreatic lipase, which has no specificity for the sequence of amino acids (Marambe et al., 2011; Wu et al., 2019). So, the higher hydrolysis degree and smaller hydrolysates were easy to be obtained after flaxseed protein was treated by pancreatin (Karamać et al., 2016). Additionally, Udenigwe et al. (2012) employed the combination of pronase and trypsin to prepare the hydrolysates with anti-hypertensive activity. The obtained arginine-rich hydrolysates presented moderate anti-hypertensive and renin-inhibitory effects. Trypsin could specifically hydrolyze peptide bonds between carboxylic acid group of lysine or argnine, and thus the hydrolyasates with arginine residues were generally generated (Udenigwe et al., 2012; Wu et al., 2019).

In order to improve enzymatic hydrolysis efficiency and the recovery of flaxseed protein hydrolysates, Marie et al. (2019) used the combination of high hydrostatic pressure and electrodialysis with ultrafiltration membranes to produce flaxseed protein hydrolysates. The results indicated that the hydrolysates in $\mathrm{KCl}$ fraction were rich in arginine, and could decrease blood pressure in rats with spontaneously hypertension.

\subsection{Antioxidant capacity}

The antioxidant ability of flaxseed protein hydrolysates highly depends on many factors, such as molecular weight of the hydrolysates, amino acid composition, the types of enzyme, pretreatment methods for flaxseed protein (Marambe \& Wanasundara, 2017; Nwachukwu \& Aluko, 2018a, b; Udenigwe et al., 2009). Logarušić et al. (2020) investigated in vitro antioxidant abilities of flaxseed protein hydrolysates prepared by Alcalase, Neutrase and Protamex, respectively. The authors indicated that the obtained flaxseed protein hydrolysates from alcalase showed the strongest antioxidant ability, whereas those obtained by Neutrase and Protamex exhibited lower or no antioxidant ability at all. Udenigwe et al. (2009) employed various proteases to produce flaxseed protein hydrolysates, and found that the hydrolysates generated by alcalase exhibited the highest DPPH. scavenging ability compared to other proteases hydrolysates. The reason for the difference was related to the specificity of proteases. In the same group, Udenigwe \& Aluko (2010) reported that the hydrolysates with a high-Fischer-ratio showed lower $\cdot \mathrm{OH}$ scavenging activity compared to those with low molecular weight hydrolysates. It might be attributed to the low phenylalanine content in the hydrolysates. However, the hydrolysates with high-Fischerratio showed higher O2.- scavenging ability compared to the hydrolysates with low molecular weight. Similarly, Hwang et al. (2016) reported that the hydrolysates with low molecular weight exhibited higher ABTS free radical-scavenging activity than high molecular weight hydrolysates, whereas the hydrolysates with high molecular weight presented the better reducing power ability compared to those of Vitamin E, Vitamin C, and BHA. Recently, Sarabandi \& Jafari (2020a) also found the hydrolysis by Alcalase could significantly increase the release of antioxidant amino acids from DFM. The hydrolysates with low molecular weights $(<10 \mathrm{kDa})$ exhibited the highest scavenging capacities for $\mathrm{DPPH}^{-}$and $\mathrm{ABTS}^{+}$free radicals.

Luna-Vital et al. (2015) reported that the excellent antioxidant ability of the hydrolysates was due to hydrophobic amino acids, such as glycine, phenylalanine, tryptophane, cysteine or alanine, in the N-terminus of the hydrolysates. Besides, in the study of Silva et al. (2017), flaxseed protein hydrolysates were obtained by the hydrolysis of alcalase, and showed notable antioxidant activity. The authors speculated that hydrophobic amino acids in the hydrolysates contributed to good antioxidant activity of the hydrolysates. Additionally, after flaxseed protein was treated by high hydrostatic pressure (HHP) before the hydrolysis, the antioxidant activity of the hydrolysates could be improved further. The reason was that the structure of flaxseed protein was destroyed by HHP treatment, and led to the more release of the antioxidant hydrolysates. Perreault et al. (2017) reported that the hydrolysates from HHP-treated flaxseed protein after enzymatic hydrolysis showed a higher antioxidant capacity than non-pretreated hydrolysates. Franck et al. (2019) carried out the hydrolysis of flaxseed protein by typsin under HHP, and indicated that the hydrolysis of flaxseed protein by typsin at $300 \mathrm{MPa}$ for 5 and $10 \mathrm{~min}$ could improve the antioxidant activity of the hydrolysates by 39 and 55\%, respectively, compared to untreated samples.

\subsection{Other beneficial activities}

Besides anti-hypertensive and antioxidant activities, many other beneficial activities of flaxseed protein hydrolysates including anti-inflammation activity, antibacterial activity, and anti-diabetic ability, have been investigated (Wu et al., 2019). The hydrolysates with low molecular weight generated by using proteases such as pepsin, ficin, and papain, could inhibit the production of lipopolysaccharide-induced NO in RAW 264.7 macrophages. It was indicated that the hydrolysates showed anti-inflammatory activity (Udenigwe et al., 2009). Doyen et al. (2014) obtained specific cationic hydrolysates from flaxseed protein, and found it had an anti-diabetic ability after being evaluated in L6 cells.

Hwang et al. (2016) found that flaxseed protein hydrolysates with low molecular weight $(<1 \mathrm{kDa})$ obtained by protease, showed better antibacterial ability against $E$. coli BCRC11634 and P. aeruginosa BCRC10944 compared to other hydrolysates with different molecular weights. Xu et al. (2008a, b) reported that flaxseed protein had antifungal activities against Candida albicans, Alternaria solani, and Aspergillus flavus. 
Flaxseed protein hydrolysates can inhibit nNOS activity, and exhibit calmodulin (CaM)-binding activity (Udenigwe \& Aluko, 2012). Omoni \& Aluko (2006a, b) obtained flaxseed protein hydrolysates by the use of alcalase. The results showed that $<1 \mathrm{kDa}$ peptide hydrolysates exhibited CaM-binding activity. Udenigwe \& Aluko (2012) obtained cationic flaxseed protein hydrolysates with the inhibition of CaM dependent phosphodiesterase activity. It was indicated that cationic hydrolysates could potentially enhance its use in treating cardiovascular disease with many symptoms.

\section{Potential applications of flaxseed protein in foods}

At present, the potential applications of flaxseed protein in foods are relatively limited. Flaxseed protein concentrates (LINOPROT 55) and its applications in real food systems such as dairy products, pastries, and meat, have been studied by the Finnish company of Flaxseed protein Ltd (Rabetafika et al., 2011). Glanbia Nutritionals is one of major manufacturers for flaxseed protein products ranging from the concentrates to protein blends (Marambe \& Wanasundara, 2017). Some applications of flaxseed protein in foods are presented in Table 4 and 5 and Figure 1.

Flaxseed proteins used as additives in many foods such as ice creams, meat emulsions, bakery products, sauces, have been studied (Table 4). Waszkowiak \& Rudzinska (2014) determined effect of DFM on lipid oxidation in pork meatballs. The results showed that DFM could stabilize fatty acid composition in stored pork meatballs. Wang et al. (2010) showed that flaxseed protein was a good ingredient to be used in meat and ice-cream products. It was attributed to good functionalities showed by flaxseed protein. Wei et al. $(2018,2019)$ investigated the enzymolysis process for producing flaxseed protein hydrolysates with different flavor characteristics. The results showed that flaxseed protein hydrolysates with molecular weight of 128-1000 Da contributed to meat-like flavor. It was indicated that flaxseed protein hydrolysates showed a potential application in food industry as flavor enhancers.

A partial replacement of wheat flour with flaxseed protein powder can improve the nutritional value of flour-based foods (Giacomino et al., 2013). The mucilage in flaxseed meal or flaxseed protein samples can significantly affect the characteristics of the foods (Gambuś et al., 2009; Marambe \& Wanasundara, 2017; Rabetafika et al., 2011). Shearer \& Davies (2005) found that wheat flour substituted about $10-20 \%$ by flaxseed meal did not influence the texture and swelling of the foods during cooking process. In the study of Manthey et al. (2008), the firmness of fresh pasta and macaroni incorporated 15\% flaxseed meal was reduced due to the mucilage in flaxseed meal, but, the addition of flaxseed meal could prolong the shelf-life of the foods due

Table 4. Potential applications of flaxseed protein in foods.

\begin{tabular}{lccl}
\hline \multicolumn{1}{c}{ Protein sources } & Addition amount (\%) & Food systems & References \\
\hline Defatted flaxseed protein products & $2-3.6 \%$ & Meat emulsion & Dev \& Quensel (1989) \\
Defatted flaxseed protein products & 1 and 3\% & Canned fish sauce & Dev \& Quensel (1989) \\
Defatted flaxseed meal & $3.0 \%$ & Pork meatballs & Waszkowiak \& Rudzinska (2014) \\
Defatted flaxseed protein products & 0.5 and 1.0\% & Ice cream & Dev \& Quensel (1989) \\
Flaxseed meal & $5-20 \%$ & White bread & Koca \& Anil (2007) \\
Flaxseed meal & $5-15 \%$ & Bagel & Alpaslan \& Hayta (2006) \\
Defatted flaxseed meal & $21 \%$ & Cookie & Rodrigues et al. (2012) \\
Flaxseed meal & $15 \%$ & Bread & Conforti \& Davis (2006) \\
Flaxseed meal & $0-5.0 \%$ & Muffins & Shearer \& Davies (2005) \\
Defatted flaxseed meal & $7.5-20 \%$ & Snack & Ganorkar et al. (2016) \\
Defatted flaxseed meal & $27 \%$ & Cereal-based bars & Giacomino et al. (2013) \\
Defatted flaxseed meal & $10-40 \%$ & Noodles & Bhise et al. (2015) \\
Flaxseed protein hydrolysates & $/$ & Meat flavor enhancers & Wei et al. (2018)
\end{tabular}

Table 5. Commercially available flaxseed protein powder.

\begin{tabular}{|c|c|c|c|}
\hline Producing company & Product name & Protein content & Applications \\
\hline \multirow[t]{2}{*}{ Glanbia Nutritionals } & Harvest ${ }^{\text {pro }}$ & $35 \%$ & Beverages, bars, bakery foods \\
\hline & Lin $^{\text {Pro }} 140$ & $38-40 \%$ & Bars, cereals, beverages \\
\hline Natunola Health & Natunola $\omega-3$ flax flour & $20 \%$ & $\begin{array}{l}\text { Bread, cookies, cereal, snacks, } \\
\text { pasta }\end{array}$ \\
\hline Xi'an Jinheng Chemical Co. Ltd, China & Jinheng & $85 \%$ & Bread, cereals, beverages, bars \\
\hline Sanyuan Longsheng Biotechnology Co. Ltd, China & Longsheng & $70 \%$ & Bread, cereals, beverages, bars \\
\hline Xi'an Sinuote Biotechnology Co. Ltd, China & Sinuote & $50 \%$ & Meat \\
\hline Xian Shuangrui Biotechnology Co. Ltd, China & SXSR & $30,50 \%$ & Bars, bakery foods, beverages \\
\hline Jiangxi Muentang Bioetchnology Co. Ltd, China & Muentang & $\begin{array}{l}40 \% \text { flaxseed protein, } 10 \% \\
\text { whey protein }\end{array}$ & Beverages \\
\hline
\end{tabular}



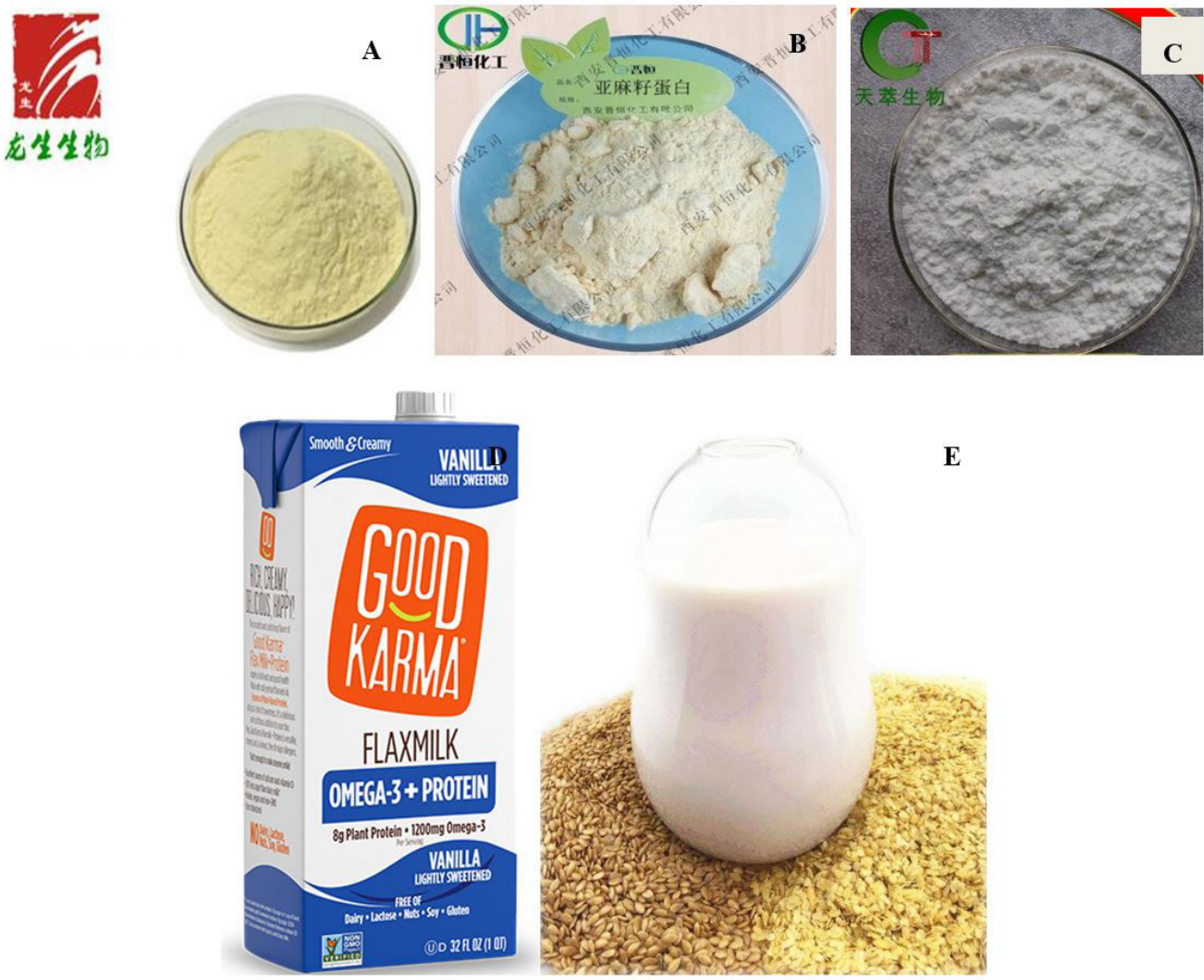

Figure 1. Flaxseed protein powders and flaxseed protein beverages. A: 70\% content of protein; B: 85\% content of protein; C: flaxseed protein instant powder; D: flax milk; E: flaxseed protein beverage.

to the antifungal ability of flaxseed protein. Wu et al. (2009) also showed that the incorporation of flaxseed meal could improve the viscoelasticity of extruded pastes because of the interaction of starch, the mucilage, and protein. Bhise et al. (2015) developed the noodles using texturized defatted meal from flaxseed, sunflower, and soybean. The results of acceptability tests showed that the noodles with $10 \%$ texturized defatted meal of flaxseed and sunflower exhibited the highest overall scores. Drozlowska et al. (2020) investigated the effect of flaxseed meal extract on physiochemical properties of low fat mayonnaises. The oil phase was partially replaced by $5 \%, 10 \%, 15 \%$ of flaxseed meal extract. The results showed that the replacement could improve the stability of mayonnaise, indicating that flaxseed meal extract could be used as a fat replacer to manufacture mayonnaises with low fat content and healthy flaxseed protein.

Flaxseed meal is rich in flaxseed protein, which has also been investigated for the applications in the baking field (Table 4; Ganorkar et al., 2016; Rodrigues et al., 2012). Lipilina \& Ganji (2009) studied the applications of flaxseed meal in breads and muffins. The results showed that incorporation $30 \%$ and $50 \%$ of flaxseed meal into breads and muffins, respectively, could form the crust with a dark colour due to Maillard reaction between the mucilage and protein. According to Pohjanheimo et al. (2006), the breads made using flaxseed meal flour had lower firmness and higher moisture holding ability compared to flaxseed-free breads. The breads with high concentration of flaxseed meal had a lower crispness. The mucilage in flaxseed meal may be attributed to these characteristics (Lipilina \& Ganji, 2009; Rabetafika et al., 2011). The consumer acceptability is one of important key factors to flaxseed protein-based products. Some sensory evaluation indicated that the maximum of 25 and $10 \%$ incorporation in cookies and breads, respectively, was suggested (Alpaslan \& Hayta, 2006; Hussain et al., 2006). Rodrigues et al. (2012) performed a sensory evaluation of irradiated flaxseed cookies. The sensory results showed that there was not significantly different between irradiated flaxseed cookies and control cookies.

Many flaxseed-based products have been also developed in our group, some of which are commercialized (Tang et al., 2016a, b, c, d, 2017; Tang \& Bian, 2018a, b, c, d; Tang, 2019a, b). Recently, we developed liquid flaxseed drinks based dehulled flaxseed meal enriched with flaxseed protein and flaxseed oil (Tang \& Bian, 2018c, d). As many other plant protein drinks, dehulled flaxeed is treated by milling and homogenizing in order to obtain stable flaxseed protein-enriched beverage. It has been marketed since 2018. The shelf life of the obtained flaxseed protein-enriched beverage can reach more than 10 months. We also have developed flaxseed yogurt using dehulled flaxseed as raw material. Dehulled milled flaxseed and milk are co-fermented by Streptococcus thermophilus and Lactobacillus bulgaricus. This type of flaxseed yogurt is very beneficial for menopause women (Tang, 2019a, b). 


\section{Conclusion}

As other oilseed proteins, flaxseed protein possesses many functional characteristics, for example water/oil adsorption ability, emulsifying ability, foaming ability and stability. Regarding flaxseed protein hydrolysates, it also can provide several health promoting benefits, particularly anti-hypertensive and antioxidant activities. Therefore, it shows a potential utilization value as a functional additive in food industry. Some applications of flaxseed protein in food systems such as the emulsification, meat analogs, wheat flour substitute, muffins, breads, and ice cream, have been investigated. However, the development of flaxseed protein is still facing many challenges. At present, the development of large-scale production for flaxseed protein is highly desired. More extensive research on flaxseed protein and its hydrolysates, such as the studies regarding the structure modification technologies, the mechanisms for their health benefits, should be carried out. As the pursuing for healthy foods, we sure that more flaxseed protein-based products will be available in the future.

\section{Conflict of interest}

None.

\section{Acknowledgements}

This work was supported by Scientific Innovation Teams in Tourism College of Zhejiang (No. 2021TDDS03) and Research Foundation of Education Department of Zhejiang (No.Y202147210).

\section{References}

Akbarbaglu, Z., Jafari, S. M., Sarabandi, K., Mohammadi, M., Heshmati, M. K., \& Pezeshki, A. (2019). Influence of spray drying encapsulation on the retention of antioxidant properties and microstructure of flaxseed protein hydrolystates. Colloids and Surfaces. B, Biointerfaces, 178, 421-429. http://dx.doi.org/10.1016/j.colsurfb.2019.03.038. PMid:30908998.

Alpaslan, M., \& Hayta, M. (2006). The effects of flaxseed, soy and corn flours on the textural and sensory properties of a bakery product. Journal of Food Quality, 29(6), 617-627. http://dx.doi. org/10.1111/j.1745-4557.2006.00099.x.

Arntfield, S. D. (2018). Proteins from oil-producing plants. In Y. D. Rada (Ed.), Proteins in food processing (pp. 187-221). UK: Woodhead publications. http://dx.doi.org/10.1016/B978-0-08-100722-8.00008-5.

Bakowska-Barczak, A., Larminat, M. A., \& Kolodziejczyk, P. P. (2020). The application of flax and hempseed in food, nutraceutical and personal care products. In R. M. Kozlowski \& M. M. Talarczyk (Eds.), Handbook of natural fibers (pp. 557-590). UK: Academics Press. http://dx.doi.org/10.1016/B978-0-12-818782-1.00017-1.

Bekhit, A. E. A., Shavandi, A., Jodjaja, T., Birch, J., Teh, S., Ahmed, I. A. M., Al-Juhaimi, F. Y., Saeedi, P., \& Bekhit, A. A. (2018). Flaxseed: composition, deoxification, utilization, and opportunities. Biocatalysis and Agricultural Biotechnology, 13, 129-152. http:// dx.doi.org/10.1016/j.bcab.2017.11.017.

Bhise, S., Kaur, A., \& Aggarwal, P. (2015). Development of protein enriched noodles using texturized defatted meal from sunflower, flaxseed and soybean. Journal of Food Science and Technology, 52(9), 5882-5889. http://dx.doi.org/10.1007/s13197-014-1630-1. PMid:26345004.
Chung, M. W. Y., Lei, B., \& Li-Chan, E. C. Y. (2005). Isolation and structural characterization of the major protein fraction from NorMan flaxseed (Linum usitatissimum L.). Food Chemistry, 90(12), 271-279. http://dx.doi.org/10.1016/j.foodchem.2003.07.038.

Conforti, F. D., \& Davis, S. F. (2006). The effect of soya flour and flaxseed as a partial replacement for bread flour in yeast bread. International Journal of Food Science \& Technology, 41(s2), 95-101. http://dx.doi. org/10.1111/j.1365-2621.2006.01410.x.

Dash, K. K., Kumar, A., Kumari, S., \& Malik, M. A. (2021). Silver nanoparticle incorporated flaxseed-alginate composite films: effect of physicochemical, mechanical, and thermal properties. Journal of Polymers and the Environment, 29(11), 3649-3659. http://dx.doi. org/10.1007/s10924-021-02137-y.

Dev, D. K., \& Quensel, L. (1989). Functional properties of linseed protein products containing different levels of mucilage in selected food systems. Journal of Food Science, 54(1), 183-186. http://dx.doi. org/10.1111/j.1365-2621.1989.tb08597.x.

Doyen, A., Udenigwe, C. C., Mitchell, P. L., Marette, A., Aluko, R. E., \& Bazinet, L. (2014). Anti-diabetic and antihypertensive activities of two flaxseed protein hydrolysate fractions revealed following their simultaneous separation by electrodialysis with ultrafiltration membranes. Food Chemistry, 145, 66-76. http://dx.doi.org/10.1016/j. foodchem.2013.07.108. PMid:24128450.

Drozlowska, E., Lopusiewicz, L., Mezynska, M., \& Bartkowiak, A. (2020). The effect of native and denaturated flaxseed meal extract on physiochemical properties of low fat mayonnaises. Journal of Food Measurement and Characterization, 14(2), 1135-1145. http:// dx.doi.org/10.1007/s11694-019-00363-6.

Food and Agriculture Organization - FAO. (2020). Retrieved from http://www.fao.org/faostat/zh/\#data/QC

Franck, M., Perreault, V., Suwal, S., Marciniak, A., Bazinet, L., \& Doyen, A. (2019). High hydrostatic pressure-assisted enzymatic hydrolysis improved protein digestion of flaxseed protein isolate and generation of peptides with antioxidant activity. Food Research International, 115, 467-473. http://dx.doi.org/10.1016/j.foodres.2018.10.034. PMid:30599966.

Gambuś, H., Gambuś, F., Pastuszka, D., Wrona, P., Ziobro, R., Sabat, R., Mickowska, B., Nowotna, A., \& Sikora, M. (2009). Quality of gluten-free supplemented cakes and biscuits. International Journal of Food Sciences and Nutrition, 60(Suppl. 4), 31-50. http://dx.doi. org/10.1080/09637480802375523. PMid:19330630.

Ganorkar, P. M., Patel, J. M., Shah, V., \& Rangrej, V. V. (2016). Defatted flaxseed meal incorporated corn-rice flour blend based extruded product by response surface methodology. Journal of Food Science and Technology, 53(4), 1867-1877. http://dx.doi.org/10.1007/s13197015-2134-3. PMid:27413213.

Giacomino, S., Peñas, E., Ferreyra, V., Pellegrino, N., Fournier, M., Apro, N., Carrión, M. O., \& Frias, J. (2013). Extruded flaxseed meal enhances the nutritional quality of cereal-based products. Plant Foods for Human Nutrition (Dordrecht, Netherlands), 68(2), 131136. http://dx.doi.org/10.1007/s11130-013-0359-8. PMid:23640296.

Hall, C., Tulbek, M. C., \& Xu, Y. (2006). Flaxseed. In S. L. Taylor (Ed.), Advance in food and nutrition research (pp. 1-97). Boston: Elsevier.

Hussain, S., Anjum, F. M., Butt, M. S., Khan, M. I., \& Asghar, A. (2006). Physical and sensoric attributes of flaxseed flour supplemented cookies. Turkish Journal of Biology, 30, 87-92.

Hwang, C. F., Chen, Y. A., Luo, C., \& Chiang, W. D. (2016). Antioxidant and antibacterial activities of peptide fractions from flaxseed protein hydrolysed by protease from Bacillus altitudinis HK02. International Journal of Food Science \& Technology, 51(3), 681-689. http://dx.doi. org/10.1111/ijfs.13030. 
Juodeikiene, G., Zadeike, D., Trakselyte-Rupsiene, K., Gasauskaite, K., Bartkiene, E., Lele, V., Viskelis, P., Bernatoniene, J., Ivanauskas, L., \& Jakstas, V. (2020). Functionalisation of flaxseed proteins assisted by ultrasonication to produce coatings enriched with raspberries phytochemicals. Lebensmittel-Wissenschaft + Technologie, 124, 109180. http://dx.doi.org/10.1016/j.lwt.2020.109180.

Karaca, A. C., Low, N., \& Nickerson, M. (2011). Emulsifying properties of canola and flaxseed protein isolates produced by isoelectric precipitation and salt extraction. Food Research International, 44(9), 2991-2998. http://dx.doi.org/10.1016/j.foodres.2011.07.009.

Karamać, M., Kosińskacagnazzo, A., \& Kulczyk, A. (2016). Use of different proteases to obtain flaxseed protein hydrolysates with antioxidant activity. International Journal of Molecular Sciences, 17(7), 1027-1039. http://dx.doi.org/10.3390/ijms17071027. PMid:27367678.

Kaushik, P., Dowling, K., McKnight, S., Barrow, C. J., Wang, B., \& Adhikari, B. (2016). Preparation, characterization and functional properties of flax seed protein isolate. Food Chemistry, 197(Part A), 212-220. http://dx.doi.org/10.1016/j.foodchem.2015.09.106. PMid:26616943.

Khan, N. A., Booker, H., \& Yu, P. (2015). Effect of heating method on alteration of protein molecular structure in flaxseed: Relationship with changes in protein subfraction profile and digestion in dairy cows. Journal of Agricultural and Food Chemistry, 63(4), 1057-1066. http://dx.doi.org/10.1021/jf503575y. PMid:25578477.

Koca, A. F., \& Anil, M. (2007). Effect of flaxseed and wheat flour blends on dough rheology and bread quality. Journal of the Science of Food and Agriculture, 8(6), 1172-1175. http://dx.doi.org/10.1002/jsfa.2739.

Krause, J. P., Schultz, M., \& Dudek, S. (2010). Effect of extraction conditions on composition, surface activity and rheological properties of protein isolations from flaxseed (Linum usitativissimum L.). Journal of the Science of Food and Agriculture, 82(9), 970-976. http://dx.doi. org/10.1002/jsfa.1140.

Kuang, X., Kong, Y., Hu, X., Li, K., Guo, X., Liu, C., Han, L., \& Li, D. (2020). Defatted flaxseed flour improves weight loss and lipid profile in overweight and obese adults: a randomized controlled trial. Food \& Function, 11(9), 8237-8247. http://dx.doi.org/10.1039/ D0FO00838A. PMid:32966475.

Lan, Y., Ohm, J. B., Chen, B., \& Rao, J. (2020). Physicochemical properties and aroma profiles of flaxseed proteins extracted from whole flaxseed and flaxseed meal. Food Hydrocolloids, 104, 105731. http://dx.doi.org/10.1016/j.foodhyd.2020.105731.

Langyan, S., Khan, F. N., Yadava, P., Alhazmi, A., Mahmoud, S. F., Saleh, D. I., Zuan, A. T. K., \& Kumar, A. (2021). In silico proteolysis and analysis of bioactive peptides from sequences of fatty acid desaturase 3 (FAD3) of flaxseed protein. Saudi Journal of Biological Sciences, 28(10), 5480-5489. http://dx.doi.org/10.1016/j.sjbs.2021.08.027. PMid:34588858.

Lei, B., Li-Chan, E. C. Y., Oomah, B. D., \& Mazza, G. (2003). Distribution of cadmium-binding components in flax (Linum usitatissimum L.) seed. Journal of Agricultural and Food Chemistry, 51(3), 814-821. http://dx.doi.org/10.1021/jf0209084. PMid:12537463.

Li, T., \& Hao, J. (2013). A peeling method and machine for flaxseeds. CN: 201310630673: A.

Lim, C. W., Norziah, M. H., \& Lu, H. F. S. (2010). Effect of flaxseed oil towards physico-chemical and sensory characteristic of reduced fat ice creams and its stability in ice creams upon storage. International Food Research Journal, 17, 393-403.

Lipilina, E., \& Ganji, V. (2009). Incorporation of ground flaxseed into bakery products and its effect on sensory and nutritional characteristics: a pilot study. Journal of Food Service, 20(1), 52-59. http://dx.doi.org/10.1111/j.1748-0159.2008.00124.x.
Liu, J., Shim, Y. Y., Tse, T. J., Wang, Y., \& Reaney, M. J. T. (2018). Flaxseed gum a versatile natural hydrocolloid for food and nonfood applications. Trends in Food Science \& Technology, 75, 146-157. http://dx.doi.org/10.1016/j.tifs.2018.01.011.

Logarušić, M., Radošević, K., Bis, A., Panić, M., Slivac, I., \& Srček, V. G. (2020). Biological potential of flaxseed protein hydrolysates obtained by different proteases. Plant Foods for Human Nutrition, 75(4), 518-524. http://dx.doi.org/10.1007/s11130-020-00841-z. PMid:32766942.

Luna-Vital, D. A., Mojica, L., Mejía, E. G., Mendoza, S., \& LoarcaPiña, G. (2015). Biological potential of protein hydrolysates and peptides from common bean (Phaseolus vulgaris L.): a review. Food Research International, 76, 39-50. http://dx.doi.org/10.1016/j. foodres.2014.11.024.

Lv, B., \& Huang, C.X. (2015). Flaxseed sprouted powder and a preparation method thereof. CN 201510030685: A.

Madhusudhan, K. T., \& Singh, N. (1985a). Effect of detoxification treatment on the physicochemical properties of linseed proteins. Journal of Agricultural and Food Chemistry, 33(6), 1219-1222. http:// dx.doi.org/10.1021/jf00066a051.

Madhusudhan, K. T., \& Singh, N. (1985b). Isolation and characterization of the major fraction (12S) of linseed proteins. Journal of Agricultural and Food Chemistry, 33(4), 673-677. http://dx.doi.org/10.1021/ jf00064a026.

Manthey, F., Sinha, S., Wolf-Hall, C., \& Hall, C. III (2008). Effect of flaxseed flour and packaging on shelf life of refrigerated pasta. Journal of Food Processing and Preservation, 32(1), 75-87. http:// dx.doi.org/10.1111/j.1745-4549.2007.00166.x.

Marambe, H. K., \& Wanasundara, J. P. D. (2017). Protein from flaxseed (Linum usitatissimum L.). In S. R. Nadathur, J.P.D. Wanasundara \& L. Scanlin (Eds.), Sustainable protein sources (pp. 133-144). UK: Academics Press. http://dx.doi.org/10.1016/B978-0-12-8027783.00008-1.

Marambe, H. K., Shand, P. J., \& Wanasundara, J. P. D. (2011). Release of angiotensin I-converting enzyme inhibitory peptides from flaxseed (Linum usitatissimum L.) protein under simulated gastrointestinal digestion. Journal of Agricultural and Food Chemistry, 59(17), 9596-9604. http://dx.doi.org/10.1021/jf202000e. PMid:21776963.

Marambe, H. K., Shand, P. J., \& Wanasundara, J. P. D. (2013). In vitro digestibility of flaxseed (Linum usitatissimum L.) protein: effect of seed mucilage, oil and thermal processing. International Journal of Food Science \& Technology, 48(3), 628-635. http://dx.doi.org/10.1111/ ijfs. 12008 .

Marambe, P. W. M. L. H. K., Shand, P. J., \& Wanasundara, J. P. D. (2008). An in vitro investigation of selected biological activities of hydrolyzed flaxseed (Linum usitatissimum L.) proteins. Journal of the American Oil Chemists' Society, 85(12), 1155-1164. http://dx.doi. org/10.1007/s11746-008-1293-z.

Marie, G. C. U., Perreault, V., Henaux, L., Carnovale, V., Aluko, R. E., Marette, A., Doyen, A., \& Bazinet, L. (2019). Impact of a high hydrostatic pressure pretreatment on the separation of bioactive peptides from flaxseed protein hydrolysates by electrodialysis with ultrafiltration membranes. Separation and Purification Technology, 211, 242-251. http://dx.doi.org/10.1016/j.seppur.2018.09.063.

Martínez-Flores, H., Barrera, E., Garnica-Romo, M., Penagos, C., Saavedra, J., \& Macazaga-Alvarez, R. (2006). Functional characteristics of protein flaxseed concentrate obtained applying a response surface methodology. Journal of Food Science, 71(8), 495-498. http://dx.doi. org/10.1111/j.1750-3841.2006.00147.x.

Mohamed, R. S., Fouda, K., \& Akl, E. M. (2020). Hepatorenal protective effect of flaxseed protein isolate incorporated in lemon juice against 
lead toxicity in rats. Toxicology Reports, 7, 30-35. http://dx.doi. org/10.1016/j.toxrep.2019.12.001. PMid:31890606.

Mridula, D., Barnwal, P., Gurumayum, S., \& Singh, K. K. (2014). Effect of chemical pretreatment on dehulling parameters of flaxseed ( $c v$. Garima). Journal of Food Science and Technology, 51(9), 2228-2233. http://dx.doi.org/10.1007/s13197-012-0699-7. PMid:25190888.

Mueller, K., Eisner, P., Yoshie-Stark, Y., Nakada, R., \& Kirchhoff, E. (2010). Functional properties and chemical composition of fractionated brown and yellow linseed meal (Linum usitatissimum L.). Journal of Food Engineering, 98(4), 453-460. http://dx.doi.org/10.1016/j. jfoodeng.2010.01.028.

Nasrabadi, M. N., Goli, S. A. H., Doost, A. S., Roman, B., Dewettinck, K., Stevens, C. V., \& Van Der Meeren, P. V. (2019). Plant based pickering stabilization of emulsions using soluble flaxseed protein and mucilage nano-assemblies. Colloids and Surfaces A: Physicochemical and Engineering Aspects, 563, 170-182. http://dx.doi.org/10.1016/j. colsurfa.2018.12.004.

Nie, C., Qin, X., Duan, Z., Huang, S., Yu, X., Deng, Q., Xiang, Q., \& Geng, F. (2021). Comparative structural and techno-functional elucidation of full-fat and defatted flaxseed extracts: implication of atmospheric pressure plasma jet. Journal of the Science of Food and Agriculture, 102(2), 823-835. PMid:34232506.

Nwachukwu, I. D., \& Aluko, R. E. (2018a). Antioxidant properties of flaxseed protein hydrolysates: influence of hydrolytic enzyme concentration and peptide size. Journal of the American Oil Chemists' Society, 95(8), 1105-1118. http://dx.doi.org/10.1002/aocs.12042.

Nwachukwu, I. D., \& Aluko, R. E. (2018b). Physicochemical and emulsification properties of flaxseed (Linum usitatissimum L.) albumin and globulin fractions. Food Chemistry, 255, 216-225. http://dx.doi.org/10.1016/j.foodchem.2018.02.068. PMid:29571469.

Nwachukwu, I. D., Girgih, A. T., Malomo, S. A., Onuh, J. O., \& Aluko, R. E. (2014). Thermoase-derived flaxseed protein hydrolysates and membrane ultrafiltration peptide fractions have systolic blood pressurelowering effects in spontaneously hypertensive rats. International Journal of Molecular Sciences, 15(10), 18131-18147. http://dx.doi. org/10.3390/ijms151018131. PMid:25302619.

Omoni, A. O., \& Aluko, R. E. (2006a). Effect of cationic flaxseed protein hydrolysate fractions on the in vitro structure and activity of calmodulin-dependent endothelial nitric oxide synthase. Molecular Nutrition \& Food Research, 50(10), 958-966. http://dx.doi.org/10.1002/ mnfr.200600041. PMid:16967519.

Omoni, A. O., \& Aluko, R. E. (2006b). Mechanism of the inhibition of calmodulin-dependent neuronal nitric oxide synthase by flaxseed protein hydrolysates. Journal of the American Oil Chemists' Society, 83(4), 335-340. http://dx.doi.org/10.1007/s11746-006-1209-8.

Oomah, B. D. (2001). Flaxseed as a functional food source. Journal of the Science of Food and Agriculture, 81(9), 889-894. http://dx.doi. org/10.1002/jsfa.898.

Oomah, B. D., \& Mazza, G. (1993). Processing of flaxseed meal: effect of solvent extraction on physicochemical characteristics. Lebensmittel-Wissenschaft + Technologie, 26(4), 312-317. http:// dx.doi.org/10.1006/fstl.1993.1064.

Perreault, V., Henaux, L., Bazinet, L., \& Doyen, A. (2017). Pretreatment of flaxseed protein isolate by high hydrostatic pressure: impacts on protein structure, enzymatic hydrolysis and final hydrolysate antioxidant capacities. Food Chemistry, 221, 1805-1812. http://dx.doi. org/10.1016/j.foodchem.2016.10.100. PMid:27979166.

Pham, L. B., Wang, B., Zisu, B., \& Adhikari, B. (2019a). Complexation between flaxseed protein isolate and phenolic compounds: effect on interfacial, emulsifying and antioxidant properties of emulsions.
Food Hydrocolloids, 94, 20-29. http://dx.doi.org/10.1016/j. foodhyd.2019.03.007.

Pham, L. B., Wang, B., Zisu, B., \& Adhikari, B. (2019b). Covalent modification of flaxseed protein isolate by phenolic compounds and the structure and functional properties of the adducts. Food Chemistry, 293, 463-471. http://dx.doi.org/10.1016/j.foodchem.2019.04.123. PMid:31151635.

Pham, L. B., Wang, B., Zisu, B., Truong, T., \& Adhikari, B. (2020). Microencapsulation of flaxseed oil using polyphenol-adducted flaxseed protein isolate-flaxseed gum complex coacervates. Food Hydrocolloids, 107, 105944. http://dx.doi.org/10.1016/j.foodhyd.2020.105944.

Pohjanheimo, T. A., Hakala, M. A., Tahvonen, R. L., Salminen, S. J., \& Kallio, H. P. (2006). Flaxseed in bread making: effects on sensory quality, aging, and composition of bakery products. Journal of Food Science, 71(4), 343-348. http://dx.doi.org/10.1111/j.17503841.2006.00005.x.

Rabetafika, H. N., Van Remoortel, V. V., Danthine, S., Paquot, M., \& Blecker, C. (2011). Flaxseed proteins: food uses and health benefits. International Journal of Food Science \& Technology, 46(2), 221-228. http://dx.doi.org/10.1111/j.1365-2621.2010.02477.x.

Ribeiro, B. D., Barreto, D. W., \& Coelho, M. A. (2013). Enzymeenhanced extraction of phenolic compounds and proteins from flaxseed meal. ISRN Biotechnology, 2013, 521067. http://dx.doi. org/10.5402/2013/521067. PMid:25969774.

Rodrigues, R. T., Fanaro, G. B., Duarte, R. C., Koike, A. C., \& Villavicencio, A. L. C. H. (2012). A sensory evaluation of irradiated cookies made from flaxseed meal. Radiation Physics and Chemistry, 81(8), 11571159. http://dx.doi.org/10.1016/j.radphyschem.2012.02.001.

Sa, A. G. A., Silva, D. G., Pacheco, M. T. B., Moreno, Y. M. F., \& Carciofi, B. A. M. (2021). Oilseed by-products as plant-based protein sources: amino acid profile and digestibility. Future Foods, 3, 100023. http:// dx.doi.org/10.1016/j.fufo.2021.100023.

Safdar, B., Pang, Z., Liu, X., Rashid, M. T., \& Jatoi, M. A. (2020). Structural and functional properties of raw and defatted flaxseed flour and degradation of cyanogenic contents using different processing methods. Journal of Food Process Engineering, 43(6), e13406. http:// dx.doi.org/10.1111/jfpe.13406.

Sammour, R. H. (1999). Proteins of linseed (Linum usitatissimum L.), extraction and characterization by electrophoresis. Botanical Bulletin of Academia Sinica, 40, 121-126.

Sammour, R. H., El-Shourbagy, M. N., Abo-Shady, A. M., \& Abasary, A. M. (1994). The seed proteins of linseed (Linum usitativissimum L.). Bulletin of Botany Academia Sinica, 35, 171-177.

Sarabandi, K., \& Jafari, S. M. (2020a). Fractionation of flaxseed-derived bioactive peptides and their influence on nanoliposomal carriers. Journal of Agricultural and Food Chemistry, 68(51), 15097-15106. http://dx.doi.org/10.1021/acs.jafc.0c02583. PMid:33290068.

Sarabandi, K., \& Jafari, S. M. (2020b). Improving the antioxidant stability of flaxseed peptide fractions during spray drying encapsulation by surfactants: physicochemical and morphological features. Journal of Food Engineering, 286, 110131. http://dx.doi.org/10.1016/j. jfoodeng.2020.110131.

Sharma, M., \& Saini, C. S. (2021). Postharvest shelf-life extension of fresh-cut guavas (Psidium guajava) using flaxseed protein-based composite coatings. Food Hydrocolloids for Health, 1, 100015. http:// dx.doi.org/10.1016/j.fhfh.2021.100015.

Shearer, A. E. H., \& Davies, C. G. A. (2005). Physicochemical properties of freshly baked and stored whole-wheat muffins with and without flaxseed meal. Journal of Food Quality, 28(2), 137-153. http://dx.doi. org/10.1111/j.1745-4557.2005.00004.x. 
Shevkani, K., Singh, N., Kaur, A., \& Rana, J. C. (2015). Structural and functional characterization of kidney bean and field pea protein isolates: a comparative study. Food Hydrocolloids, 43, 679-689. http:// dx.doi.org/10.1016/j.foodhyd.2014.07.024.

Shi, J., Xiao, J., Liu, L., \& Dong, X. (2021). Ultrasonic assisted oil-inwater emulsions stabilized by flaxseed protein isolate: influence of different oils. Journal of Dispersion Science and Technology, 1-12. http://dx.doi.org/10.1080/01932691.2021.1880923.

Shim, Y. Y., Gui, B., Wang, Y., \& Reaney, M. J. T. (2015). Flaxseed (Linum usitatissimum L.) oil processing and selected products. Trends in Food Science \& Technology, 43(2), 162-177. http://dx.doi. org/10.1016/j.tifs.2015.03.001.

Silva, F. G. D., Hernandez-Ledesma, B., Amigo, L., Netto, F. M., \& Miralles, B. (2017). Identification of peptides released from flaxseed (Linum usitatissimum) protein by Alclase hydrolysis: antioxidant activity. Lebensmittel-Wissenschaft + Technologie, 76, 140-146. http:// dx.doi.org/10.1016/j.lwt.2016.10.049.

Slominski, B. A., Meng, X., Campbell, L. D., Guenter, W., \& Jones, O. (2006). The use of enzyme technology for improved energy utilization from full-fat oilseeds. Part II: Flaxseed. Poultry Science, 85(6), 10311037. http://dx.doi.org/10.1093/ps/85.6.1031. PMid:16776472.

Song, X., Zhang, L., Jing, C., Kang, Q., Wu, G., Jiang, W., \& Yuan, H. (2017). Study on degumming process of flaxseed by enzymatic hydrolysis. Heilongjiang Nongye Kexue, 12, 67-69.

Tang, Z. X. (2019a). Flaxseed fat-reducing yogurt nutrition bar and a preparation method thereof. CN 201910603833.X.

Tang, Z. X. (2019b). Flaxseed yogurt for women and a making method thereof. CN 201910814791.

Tang, Z. X., \& Bian, J. Z. (2018a). Flaxseed nutritional food for lowing blood lipid and a preparation method thereof. CN 201811366312:A.

Tang, Z. X., \& Bian, J. Z. (2018b). Flaxseed nutritional food for strengthening brain and a production method thereof. CN 201811367137: A.

Tang, Z. X., \& Bian, J. Z. (2018c). Flaxseed protein beverage and a preparation method thereof. CN 201811252507: A.

Tang, Z. X., \& Bian, J. Z. (2018d). Nourishment enriched in proteins and flaxseed oil and a preparation method thereof. CN 201811252511.7.

Tang, Z. X., \& Bian, J. Z. (2018e). Pregnant woman food containing alpha-linolenic acid and a preparation method thereof. CN 201811367386:A.

Tang, Z. X., Liang, J. Y., \& Bian, J. Z. (2016a). Coarse cereal biscuits containing alpha-linolenic acid and a preparation method thereof. CN 201610762274: A.

Tang, Z. X., Liang, J. Y., \& Bian, J. Z. (2016b). Flaxseed milk tablets and a preparation method thereof. CN 201610757720: A.

Tang, Z. X., Liang, J. Y., \& Bian, J. Z. (2016c). Flaxseed soft sweets and a preparation method thereof. CN 201610755288: A.

Tang, Z. X., Liang, J. Y., \& Bian, J. Z. (2016d). Nutritious coarse cereal energy bar and a making method thereof. CN 201610754178: A.

Tang, Z. X., Liang, J. Y., \& Bian, J. Z. (2017). Flaxseed kernel protein beverage and a preparation method thereof. CN 201710047917: A.

Tang, Z. X., Shi, L. E., Wang, X. M., Dai, G. W., Cheng, L. A., Wan, Z. X., He, H., Wu, Q., Wang, Y. B., Jin, X. Y., Ying, R. F., \& Huang, L. H. (2020). Whole flaxseed-based products and their health benefits. Food Science and Technology Research, 26(5), 561-578. http://dx.doi. org/10.3136/fstr.26.561

Tang, Z. X., Ying, R. F., Lv, B. F., Yang, L. H., Xu, Z., Yan, L. Q., Bu, J. Z., \& Wei, Y. S. (2021). Flaxseed oil: extraction, health benefits and products. Quality Assurance and Safety of Crops \& Foods, 13(1), 1-19. http://dx.doi.org/10.15586/qas.v13i1.783.
Teh, S. S., Bekhit, A. E. A., Carne, A., \& Birch, J. (2016). Antioxidant and ACE-inhibitory activities of hemp (Cannabis sativa L.) protein hydrolysates produced by the proteases AFP, HT, Pro-G, actinidin and zingibain. Food Chemistry, 203, 199-206. http://dx.doi.org/10.1016/j. foodchem.2016.02.057. PMid:26948606.

Teh, S. S., Bekhit, E. D., Carne, A., \& Birch, J. (2014). Effect of the defatting process, acid and alkali extraction on the physicochemical and functional properties of hemp, flax and canola seed cake protein isolates. Journal of Food Measurement and Characterization, 8(2), 92-104. http://dx.doi.org/10.1007/s11694-013-9168-x.

Tirgar, M., Silcock, P., Carne, A., \& Birch, E. J. (2017). Effect of extraction method on functional properties of flaxseed protein concentrates. Food Chemistry, 215, 417-424. http://dx.doi.org/10.1016/j. foodchem.2016.08.002. PMid:27542494.

Udenigwe, C. C., \& Aluko, R. E. (2010). Antioxidant and angiotensin converting enzyme-inhibitory properties of a flaxseed proteinderived high fischer ratio peptide mixture. Journal of Agricultural and Food Chemistry, 58(8), 4762-4768. http://dx.doi.org/10.1021/ jf100149w. PMid:20218606.

Udenigwe, C. C., \& Aluko, R. E. (2011). Another side of flaxseed proteins and peptides. Agro Food Industry Hi-Tech, 22, 50-53.

Udenigwe, C. C., \& Aluko, R. E. (2012). Multifunctional cationic peptide fractions from flaxseed protein hydrolysates. Plant Foods for Human Nutrition (Dordrecht, Netherlands), 67(1), 1-9. http:// dx.doi.org/10.1007/s11130-012-0275-3. PMid:22327315.

Udenigwe, C. C., Adebiyi, A. P., Doyen, A., Li, H., Bazinet, L., \& Aluko, R. E. (2012). Low molecular weight flaxseed protein-derived argininecontaining peptides reduced blood pressure of spontaneously hypertensive rats faster than amino acid form of arginine and native flaxseed protein. Food Chemistry, 132(1), 468-475. http://dx.doi. org/10.1016/j.foodchem.2011.11.024. PMid:26434317.

Udenigwe, C. C., Lin, Y. S., Hou, W. C., \& Aluko, R. E. (2009). Kinetics of the inhibition of renin and angiotensin I-converting enzyme by flaxseed protein hydrolysate fractions. Journal of Functional Foods, 1(2), 199-207. http://dx.doi.org/10.1016/j.jff.2009.01.009.

Wanasundara, P. K. J. P. D., \& Shahidi, F. (1997). Removal of flaxseed mucilage by chemical and enzymatic treatments. Food Chemistry, 59(1), 47-55. http://dx.doi.org/10.1016/S0308-8146(96)00093-3.

Wanasundara, P. K. J. P. D., \& Shahidi, F. (2003). Flaxseed proteins: potential food applications and process-induced changes. In L. U. Thompson \& S. C. Cunnane (Eds.), Flaxseed in human nutrition (pp. 387-403). Champaign: AOCS Press. http://dx.doi. org/10.1201/9781439831915.ch21.

Wanasundara, P. K. J. P. D., Wanasundara, U. N., \& Shahidi, F. (1999). Changes in flax (Linum usitatissimum L.) seed lipids during germination. Journal of the American Oil Chemists' Society, 76(1), 41-48. http://dx.doi.org/10.1007/s11746-999-0045-z.

Wang, B., Li, D., Wang, L., \& Özkan, N. (2010). Effect of concentrated flaxseed protein on the stability and rheological properties of soybean oil-in-water emulsions. Journal of Food Engineering, 96(4), 555-561. http://dx.doi.org/10.1016/j.jfoodeng.2009.09.001.

Wang, Y., Li, D., Wang, L. J., Chiu, Y. L., Chen, X. D., Mao, Z. H., \& Song, C. F. (2008). Optimization of extrusion of flaxseeds for in vitro protein digestibility analysis using response surface methodology. Journal of Food Engineering, 85(1), 59-64. http://dx.doi.org/10.1016/j. jfoodeng.2007.06.033.

Waszkowiak, K., \& Rudzinska, M. (2014). Effect of flaxseed meal and extracts on lipid stability in a stored meat product. Journal of the American Oil Chemists' Society, 91(6), 979-987. http://dx.doi. org/10.1007/s11746-014-2438-x. PMid:24882871. 
Wei, C. K., Ni, Z. J., Thakur, K., Liao, A. M., Huang, J. H., \& Wei, Z. J. (2019). Color and flavor of flaxseed protein hydrolysates Maillard reaction products: effect of cysteine, initial $\mathrm{pH}$, and thermal treatment. International Journal of Food Properties, 22(1), 84-99. http://dx.doi. org/10.1080/10942912.2019.1573830.

Wei, C. K., Thakur, K., Liu, D. H., Zhang, J. G., \& Wei, Z. J. (2018). Enzymatic hydrolysis of flaxseed (Linum usitatissimum L.) protein and sensory characterization of Maillard reaction products. Food Chemistry, 263, 186-193. http://dx.doi.org/10.1016/j.foodchem.2018.04.120. PMid:29784306.

Wu, J.P., Muir, A.D., \& Aluko, R.E. (2009). AEC inhibitory peptides from plant materials. Patent No. US007566690B2.

Wu, S., Wang, X., Qi, W., \& Guo, Q. (2019). Bioactive protein/peptides of flaxseed: a review. Trends in Food Science \& Technology, 92, 184193. http://dx.doi.org/10.1016/j.tifs.2019.08.017.

Xu, Y., Hall, C. III, \& Wolf-Hall, C. (2008a). Antifungal activity stability of flaxseed protein extract using response surface methodology. Journal of Food Science, 73(1), M9-M14. http://dx.doi.org/10.1111/j.17503841.2007.00576.x. PMid:18211360.

Xu, Y., Hall, C. III, \& Wolf-Hall, C. (2008b). Fungistatic activity of heattreated flaxseed determined by response surface methodology. Journal of Food Science, 73(6), M250-M256. http://dx.doi.org/10.1111/j.17503841.2008.00806.x. PMid:19241553.

Yang, J., Wen, C., Duan, Y., Deng, Q., Peng, D., Zhang, H., \& Ma, H. (2021). The composition, extraction, analysis, bioactivities, bioavailability and application in food system of flaxseed (Linum usitatissimum L.) oil: a review. Trends in Food Science \& Technology, 118, 252-260. http://dx.doi.org/10.1016/j.tifs.2021.09.025.

Yoshie-Stark, Y., Müller, K., Kawarada, H., Futagawa, K., Nakada, R., \& Tashiro, Y. (2011). Functional properties of linseed meal fractions: application as nutraceutical ingredient. Food Science and Technology Research, 17(4), 301-310. http://dx.doi.org/10.3136/fstr.17.301.

Yu, X., Huang, S., Nie, C., Deng, Q., Zhai, Y., \& Shen, R. (2020). Effects of atmospheric pressure plasma jet on the physicochemical, functional, and antioxidant properties of flaxseed protein. Journal of Food Science, 85(7), 2010-2019. http://dx.doi.org/10.1111/17503841.15184. PMid:32529640.

Zardo, D. M., Dantas, A. P., Vanz, R., Wosiacki, G., \& Nogueira, A. (2009). Intensity of red pigmentation in apples and its influence on phenolic compounds content and antioxidant activity. Food Science and Technology, 29(1), 148-154. http://dx.doi.org/10.1590/ S0101-20612009000100023.

Zheng, Y. I., Wiesenborn, D. P., Tostenson, K., \& Kangas, N. (2003). Screw pressing of whole and dehulled flaxseed for organic oil. Journal of the American Oil Chemists' Society, 80(10), 1039-1045. http://dx.doi.org/10.1007/s11746-003-0817-7.

Zou, X., Chen, X., Hu, J., Wang, Y., Gong, D., Zhu, X., \& Deng, Z. (2017). Comparisons of proximate compositions, fatty acids profile and micronutrients between fiber and oil flaxseeds (Linum usitatissimum L.). Journal of Food Composition and Analysis, 62, 168-176. http:// dx.doi.org/10.1016/j.jfca.2017.06.001. 